Semina $\square \quad$ Nr 16

Scientiarum 2017

s. $118-136$

DOI: http://dx.doi.org/10.15633/ss.2487

Bartłomiej Chyłka

\title{
Od konfliktu do integracji. \\ Historia i teologiczne uzasadnienie metodologicznej odrębności \\ poznania wiary i rozumu
}

Szeroko pojęte zagadnienia relacji między rozumem a wiarą stanowią temat o niezwykle bogatej historii ${ }^{1}$. Niemniej współcześnie przeżywa on okres rozkwitu, głównie za sprawą nowych odkryć w dziedzinie filozofii nauki. Odkrycia te, na czele z przezwyciężeniem neopozytywizmu ${ }^{2}$, rezonują zwłaszcza w obszarze zmatematyzowanych nauk empirycznych (science) ${ }^{3}$, które stanowią dziś w powszechnej opinii paradygmat naukowości czy racjonalności ${ }^{4}$. Pod wpływem ich silnego rozwoju w XVIII wieku zanegowana została nie tylko racjonalność wiary, ale przede wszystkim sensowność teologii. Tryumfujący w XIX wieku pozytywizm wyparł tę ostatnią z kręgu naukowej refleksji, roszcząc sobie prawo do wyjaśnienia świata, czy też raczej spychając pytania o przyczyny jego istnienia poza nawias zainteresowania nauki. Jednak w latach sześćdziesiątych XX wieku filozofia

1 Por. Jan Paweł II, encyklika Fides et ratio [dalej: FR], Wrocław 1998, nr 3644; O. Pedersen, Konflikt czy symbioza? Z dziejów relacji pomiędzy nauka a teologia, tłum. W. Skoczny, Tarnów 1997.

2 Por. M. Heller, J. Życiński, Pasja wiedzy. Między nauka a filozofia, Kraków 2010, s. 232.

3 Por. M. Heller, Nowa fizyka i nowa teologia, Kraków 2015, s. 90.

4 Por. M. Heller, Filozofia i wszechświat. Wybór pism, Kraków 2008, s. 478. 
neopozytywistyczna padła ofiarą własnej krytyki, uświadamiając sobie, że jej podstawowe założenia są przedmiotem wiary ${ }^{5}$. Równocześnie wśród uczonych wielu dziedzin rosła świadomość, iż praca naukowa nie może obyć się bez przyjęcia wiedzy „na wiarę”, to znaczy z pominięciem jej empirycznej weryfikacji. W efekcie, jak zauważa ks. Michał Heller, „przyglądając się dzisiejszej naukowo-filozoficzno-teologicznej scenie dyskusji i polemik, jasno widać, że większości aktorów na tej scenie nie trzeba przekonywać do niezbędności me-

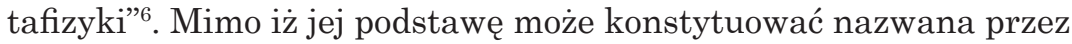
ks. Tadeusza Pabjana tzw. świecka wiara ${ }^{7}$, niebędacca wiarą religijna, opisane procesy znamionuja ponowne otwarcie nauki na teologię, która z zasady jest samokrytyczną i racjonalną refleksją nad wiarą i jako taka posiada potencjał do nawiązania dialogu z naukami ${ }^{8}$.

W pierwszej części niniejszego artykułu zaprezentuję przyczyny nieufności i rugowania teologii z obszaru nauki. Następnie przedstawię aktualny klimat dialogu między reprezentantami nauk przyrodniczych, filozofii i teologii, ze szczególnym uwzględnieniem programu teologii nauki Hellera. Wreszcie omówię koncepcję teologicznego uzasadnienia zasady metodologicznego odróżnienia rozumu i wiary autorstwa o. Wojciecha Giertycha, która w mojej ocenie w znacznej mierze pokrywa się z najnowszymi osiagnięciami filozofii nauki, stanowiąc jej uzupełnienie.

\section{Od metodologii do ontologii - konflikt}

Amerykański fizyk i teolog Ian Graeme Barbour wyróżnił cztery możliwe modele relacji między wiarą a rozumem: konflikt, nieza-

5 Por. M. Heller, J. Życiński, Pasja wiedzy..., dz. cyt., s. 232.

6 M. Heller, J. Życiński, Pasja wiedzy..., dz. cyt., s. 259.

7 Zob. T. Pabjan, Anatomia konfliktu. Między nowym ateizmem a teologiq na$u k i$, Kraków 2016, s. 28. Autor trafnie zauważa, iż w obszarze nauk przyrodniczych przesłanie empiryzmu jest osłabiane przez konieczność przyjęcia bez empirycznego sprawdzenia niemal całej posiadanej wiedzy.

8 Por. R. J. Woźniak, Przyszłość, teologia, społeczeństwo, Kraków 2007, s. 45-48; A. Anderwald, Teologia a nauki przyrodnicze. Rola wiedzy przyrodniczej $w$ dociekaniach teologicznych, Opole 2007, s. 17-26; J. Szymik, Teologia jako nauka wiary, czyli scientia sui generis, „Śląskie Studia Historyczno-Teologiczne” XXXII (1999), s. 95-104. 
leżność, dialog oraz integrację $e^{9}$ Nie wchodząc w historyczne rozważania na temat dominujących stanowisk w epokach przednowożytnych, trzeba zauważyć, iż procesem kluczowym dla zrozumienia współczesnej panoramy przekonań w tym zakresie jest powstanie nauk empirycznych w XVII wieku ${ }^{10}$. W pierwszej fazie ich rozwój znamionowała współpraca z teologią (fizykoteologia) ${ }^{11}$, jednak zapoczątkowany w filozofii Kartezjusza przesadny racjonalizm i metodologiczne rozbicie rzeczywistości na świat wiary i rozumu ${ }^{12}$ doprowadziły do zepchnięcia wiary w przestrzeń irracjonalności. Równocześnie mechanistyczne rozumienie świata sprzyjało pominięciu pytania o źródła praw fizyki, a w konsekwencji odsunięciu teologii od obszaru naukowej refleksji o rzeczywistości, co przewidział już George Berkeley ${ }^{13}$. Poznawczy optymizm przedstawicieli nauk przyrodniczych, dla których mechanika stała się nową ontologia, ciagle ewoluował, pobudzany nowymi sukcesami i odkryciami w dziedzinie fizyki, chemii czy biologii. Natomiast towarzyszący filozofii mechanistycznej deizm zepchną Boga na margines myśli filozoficznej. W takim klimacie nietrudno było o pojawienie się koncepcji Augusta Comte’a, według którego teologia nie może stać w jednym szeregu z naukami przyrodniczymi, ponieważ jej twierdzenia wymykają się pozytywistycznemu kanonowi racjonalności, jaki tworzy możliwość matematycznej lub empirycznej weryfikowalności zdań.

9 Por. I. G. Barbour, Ways of Relating Science and Technology, w: Physics, Philosophy and Theology: A Common Quest for Understanding, ed. R. J. Roussel, W. Stoeger, G. V. Coyne, Vatican City State 1988, s. 21-48. Tekst polski: I. G. Barbour, Jak uktadaja się stosunki między naukq a teologia?, tłum. S. Cyran i in., „Zagadnienia Filozoficzne w Nauce" XV (1993), s. 3-22; G. Barbour, Jak układaja się stosunki między nauka a teologiq? Cz. II, tłum. S. Cyran i in., „Zagadnienia Filozoficzne w Nauce" XVI (1994), s. 3-22.

10 Por. M. Heller, Nowa fizyka..., dz. cyt., s. 5.

11 Por. M. Heller, Nowa fizyka..., dz. cyt., s. 53. Przykładowo Izaak Newton uważał się za teologa.

12 Por. Międzynarodowa Komisja Teologiczna, W poszukiwaniu etyki uniwersalnej: nowe spojrzenie na prawo naturalne, tłum. R. Kiełtyka, Kraków 2010, nr 72; FR 34.

13 Por. M. Heller, J. Życiński, Pasja wiedzy..., dz. cyt., s. 229. 
W XIX wieku mechanicyzm znalazł rozwinięcie w idei materializmu naukowego, a więc poglądu głoszącego, iż istnieje tylko i wyłącznie materia, będąca przedmiotem mechanicznych oddziaływań ${ }^{14}$. Pogląd ten wywarł przemożny wpływ na środowisko naukowe w całym XX wieku, choć u jego źródła znajduje się błąd metodologiczny. $\mathrm{Z}$ przesłanki naturalizmu metodologicznego ${ }^{15}$ wyprowadzono błędny wniosek, iż istnieje jedynie materia.

Przyczyn popełnienia takiego błędu należy szukać przede wszystkim w światopoglądowym zapleczu dziewiętnastowiecznych naukowców. Kluczowym procesem było wspomniane wyżej wyparcie metafizyki z kręgu zdań sensownych oraz zastapienie jej fizyką. Taka zamiana, choć sama w sobie będąca jedynie filozoficzną interpretacją danych empirycznych, mogła wydawać się uzasadniona w obliczu obejmowania coraz większych obszarów rzeczywistości przez metodę matematyczno-empiryczna ${ }^{16}$. Ekspansywność tej ostatniej również współcześnie daje asumpt do totalistycznej - a więc obejmującej także kwestię istnienia - interpretacji wyników badań nauk empirycznych. Temu zjawisku sprzyja pokutująca wśród znacznych rzesz inteligencji mentalność neopozytywistyczna ${ }^{17}$, którą Jan Paweł II identyfikuje ze scjentyzmem. Jest to koncepcja filozoficzna, która uznaje za jedyną wartościową formę poznania tę właściwą dla nauk ścisłych, natomiast poznanie religijne i teologiczne spycha do sfery wyobrażeń ${ }^{18}$. W efekcie w nauce pojawiają się „filozofujący fizycy”, kreślacy przekraczające ich kompetencje tzw. naukowe wizje świa$\mathrm{ta}^{19}$. W wizjach tych nie ma miejsca nie tylko dla teologii, ale także dla odniesień metafizycznych czy moralnych ${ }^{20}$. Z tego względu war-

14 Por. T. Pabjan, Anatomia konfliktu..., dz. cyt., s. 18.

15 Jest to słuszna skądinąd „zasada metody naukowej, która głosi, że fizyka (...) powinna zajmować się jedynie obiektami i zjawiskami o charakterze fizykalnym i że w wyjaśnianiu zachowania tego typu obiektów i przebiegu tego rodzaju zjawisk dyscyplina ta musi odwoływać się jedynie do innych zjawisk i obiektów o takim właśnie charakterze" - T. Pabjan, Anatomia konfliktu..., dz. cyt., s. 19.

16 Por. M. Heller, Nowa fizyka..., dz. cyt., s. 73.

17 Por. M. Heller, Nowa fizyka..., dz. cyt., s. 111.

18 Por. FR 88.

19 Por. M. Heller, Nowa fizyka..., dz. cyt., s. 82.

20 Por. FR 46. 
to podkreślić, iż konflikt pomiędzy nauką i teologią osiagnął swój szczyt nie za czasów Galileusza czy Karola Darwina, ale w XX wieku, gdy nauka zaczęła próbować „udowadniać” poglądy ateistyczne ${ }^{21}$.

\section{Dyktat metodologii - niezależność}

Ksiądz Michał Heller w swoich licznych publikacjach podkreśla, iż neopozytywizm jest zjawiskiem zupełnie nieliczącym się w fachowej filozofii naszych czasów ${ }^{22}$. Jego schyłek datuje się na lata sześćdziesiąte XX wieku, natomiast główną przyczyną klęski tej filozofii była krytyka epistemologiczna ${ }^{23}$. Jednak jak zauważa Heller, neopozytywizm nie zniknął całkowicie z obszaru myśli filozoficznej, ale przekształcił się w różne odmiany postpozytywistycznej filozofii, jak np. filozofia nauki, filozofia analityczna czy filozofia języka ${ }^{24}$. Prądy te wywierają obecnie ogromny wpływ na uczonych i mogą pochwalić się postępami w badaniach nad relacją pomiędzy nauką i teologia. Zwłaszcza dzięki odkryciom współczesnej filozofii nauki dokonano metodologicznego odróżnienia filozofii i teologii od nauk przyrodniczych ${ }^{25}$. Uczeni uświadomili sobie dziewiętnastowieczny błąd absolutyzowania metody nauk przyrodniczych i niedozwolonego przejścia od metodologii do ontologii ${ }^{26}$. W efekcie poważna nauka postawiła sobie zdrowe granice, nie próbując już dowodzić nieistnienia rzeczywistości nieempirycznych. Tym samym przedstawiciele science zaczęli dopuszczać teologię do kręgu nauki, szanując jej autonomiczność.

Niemniej na płaszczyźnie wspólnego dialogu teologii i nauk przyrodniczych pojawiły się nowe problemy. Mit konfliktu przerodził się w przekonanie, że przepaść metodologiczna, która dzieli nauki i teologię, sięga na tyle głęboko, iż pomiędzy tymi dwiema dziedzinami nie ma

21 Por. M. Heller, J. Życiński, Pasja wiedzy..., dz. cyt., s. 230; K. Jodkowski, Spór ewolucjonizmu z kreacjonizmem. Podstawowe pojęcia i poglady, Warszawa 2007, s. 17.

22 Por. M. Heller, J. Życiński, Pasja wiedzy..., dz. cyt., s. 232.

23 Por. FR 88.

${ }_{24}$ Por. M. Heller, Nowa fizyka..., dz. cyt., s. 75-76.

25 Por. M. Heller, Nowa fizyka..., dz. cyt., s. 32.

26 Por. T. Pabjan, Anatomia konfliktu..., dz. cyt., s. 23. 
miejsca tak na dialog, jak i na jakikolwiek konflikt ${ }^{27}$. Miejsce wrogości zajęło poczucie wyobcowania, izolacji i braku wzajemnego zainteresowania. Przedstawiciele jednej i drugiej dziedziny zaczęli twierdzić, że:

(...) „poznanie empiryczne” i „poznanie filozoficzne” (analogicznie „poznanie teologiczne” czy „poznanie religijne”) znajdują się na dwóch niekrzyżujących się i wzajemnie nieprzekładalnych płaszczyznach metodologicznych, teoriopoznawczych, językowych i dlatego nauki empiryczne i filozofia (teologia, religia) są niewspółmierne, a więc zasadniczo bezkonfliktowe; ich, choćby nawet równobrzmiące, wypowiedzi niosa całkowicie różnoznaczną treśćc ${ }^{28}$.

$\mathrm{Z}$ tego względu teologia i nauki przyrodnicze nie miałyby sobie nic do powiedzenia, a światy wiary i rozumu musiałyby pozostać rozdzielone.

Zaprezentowana doktryna w znacznej mierze okazuje się słuszna. Słuszność w nauce mierzy się bowiem skutecznościa, a ścisłe metodologiczne odróżnienie teologii od nauk empirycznych przyczyniło się do wielu odkryć i postępu tak w dziedzinie nauk, jak i w obszarze samej teologii, która w zetknięciu z twardymi danymi nauk empirycznych mogła ulec oczyszczeniu ${ }^{29}$. Co więcej, doktryna ta zapewnia przedstawicielom jednej i drugiej dziedziny komfort operowania wyłącznie na dobrze znanym terenie.

\section{W stronę teologii nauki - dialog}

Niemniej - kierując się kryterium skuteczności - Heller podkreśla, iż myśl ludzka nie zadowala się uznaniem istnienia niepokonalnych barier, a metodologiczna odrębność nie musi oznaczać izolacjonizmu ${ }^{30}$. W jego ocenie:

27 Por. M. Heller, J. Życiński, Pasja wiedzy..., dz. cyt., s. 225-226.

28 M. Heller, Nowa fizyka..., dz. cyt., s. 78. Por. M. Heller, J. Życiński, Pasja wie$d z y \ldots$, dz. cyt., s. 225.

${ }_{29}$ Por. M. Heller, Wszechświat i Stowo, Kraków 1994, s. 27-38.

30 Por. M. Heller, Nowa fizyka..., dz. cyt., s. 32. 
(...) istnieją pewne typy wypowiedzi, które można przenosić z nauk empirycznych do filozofii bez popadania w „pomieszanie płaszczyzn”; co więcej, w historii filozofii i nauk empirycznych transformacje takie niejednokrotnie miały miejsce i okazywały się zwykle bardzo płodne ${ }^{31}$.

Za przykład może posłużyć wykorzystanie przez fizykę filozoficznych terminów czasu i przestrzeni. Podobne zależności można dostrzec między teologia a naukami. Rozwój wspomnianych pojęć czasu i przestrzeni oddziaływał w historii z teologicznymi interpretacjami tajemnicy wcielenia ${ }^{32}$, natomiast pojęcie masy u Izaaka Newtona zostało zaczerpnięte z trzynastowiecznych dyskusji teologicznych na temat ilości materii w Eucharystii ${ }^{33}$. Odnosząc się do przykładów bardziej współczesnych - Georges Lemaître czerpał religijną inspirację do swej hipotezy pierwotnego atomu, która następnie przerodziła się w teorię Wielkiego Wybuchu, powołując się na fragment Księgi Izajasza mówiący o Bogu ukrytym w początku stworzenia ${ }^{34}$. Wreszcie Heller przewiduje, iż tak jak pojęcia czasu i przestrzeni, również pojęcia istnienia i wartości moga niebawem przeniknaćc z obszaru filozofii do fizyki ${ }^{35}$. Nie brakuje również przykładów wykorzystania dorobku nauk empirycznych w teologii. Najbardziej charakterystycznym z nich jest ewolucja teologii stworzenia ${ }^{36}$. Duże znaczenie nauk przyrodniczych można zaobserwować także w procesie uznania przez Kościół jakiegoś zdarzenia za cud ${ }^{37}$.

Mogłoby się wydawać, iż współcześnie poszukiwanie podobnych form dialogu między teologia a naukami empirycznymi jest bezcelowe. O ile dla teologii naukowy obraz świata, na który obecnie składają się dane uzyskiwane przede wszystkim dzięki mechanice kwanto-

31 M. Heller, Nowa fizyka..., dz. cyt., s. 78.

32 Por. T. F. Torrance, Space, Time and Incarnation, Oxford 1969.

33 Por. M. Jammer, The Concepts of Mass, Cambridge 1961.

34 Por. M. Heller, J. Życiński, Pasja wiedzy..., dz. cyt., s. 244-245.

35 Por. M. Heller, Nowa fizyka..., dz. cyt., s. 86-87.

36 Zob. A. Anderwald, Teologia a nauki..., dz. cyt., s. 99-147.

37 Por. A. Anderwald, Teologia a nauki..., dz. cyt., s. 149-200; T. Pabjan, Anatomia konfliktu..., dz. cyt., s. 144-149. 
wej, teorii ewolucji i teorii względności, zawsze miał duże znaczenie ${ }^{38}$, to dla science odniesienia teologiczne sa pozbawione podstaw. Nauki empiryczne świetnie sobie radzą bez odwołania do wiary czy nawet kwestii filozoficznych. Jednak jak zauważa Heller, „spokój skutecznej metody można osiagnąć tylko za cenę metafizycznego niepokoju"39. Wynika to z faktu, iż poznanie teologiczne i poznanie empiryczne mają wspólną płaszczyznę, spotykając się w człowieku ${ }^{40}$. Stąd podejmowanie próby integralnego połaczenia tych porządków wydaje się naturalna potrzebą człowieka. Na tę potrzebę zwrócił uwagę Jan Paweł II, pisząc w encyklice Fides et ratio:

Pragnę wyrazić tutaj głębokie przekonanie - opierając się na tym, czego nauczali konsekwentnie papieże ostatnich pokoleń i co potwierdził także Sobór Watykański II - że człowiek jest w stanie wypracować sobie jednolitą i organiczną koncepcję poznania. Jest to jedno z zadań, jakie myśl chrześcijańska będzie musiała podejmować w nadchodzącym trzecim tysiącleciu ery chrześcijańskiej. Wycinkowość wiedzy wiąże się z częściową wizją prawdy i prowadzi do fragmentaryzacji sensu, a przez to uniemożliwia współczesnemu człowiekowi osiagnięcie wewnętrznej jedności ${ }^{41}$.

Nie wchodząc w kwestię filozoficznego uzasadnienia założenia przyjętego przez polskiego papieża, warto jedynie zauważyć, iż ma ono długą tradycję, a o jego poprawności świadczy pośrednio rozprawienie się z mitem konfliktu między wiarą i rozumem. Ponadto ma ono tę zaletę, iż daje nadzieję na uniknięcie duchowej schizofrenii ludziom wierzącym, którzy karmieni mentalnością pozytywistyczna mają problemy ze zbudowaniem spójnego światopoglądu ${ }^{42}$. Omawia-

38 Por. T. Pabjan, Anatomia konfliktu..., dz. cyt., s. 64. Warto zauważyć, że już przy opisie stworzenia świata z Księgi Rodzaju „autorzy biblijni posiadali (...) wizję świata, która w ich czasach była «naukowa», bo zgadzała się z ówczesnym stanem nauki. Oni z tej wizji korzystali, ale jej nie kanonizowali, nie nadawali jej charakteru niezmiennej i pełnej prawdy. Korzystali, aby przedstawić myśl nie przyrodnicza, ale religijna" - T. Jelonek, Biblijna historia zbawienia, Kraków 2004, s. 24.

39 M. Heller, J. Życiński, Pasja wiedzy..., dz. cyt., s. 233.

40 Zob. M. Heller, J. Życiński, Pasja wiedzy..., dz. cyt., s. 245.

41 FR 85.

42 Por. T. Pabjan, Anatomia konfliktu..., dz. cyt., s. 58. 
ne założenie posiada więc silną legitymizację egzystencjalną i pozwala uwolnić z więzienia irracjonalności głęboko zakorzenioną w człowieku potrzebę wiary ${ }^{43}$. Heller zwrócił na to uwagę, podkreślając, iż niewielu naukowców, nawet tych niereligijnych, zadowalało się neopozytywistyczną receptą redukcjonizmu na metafizyczny niepokój ${ }^{44}$. Szukali raczej czegoś więcej i choć ich filozoficzne interpretacje wyników badań empirycznych często bywały dyletanckie ${ }^{45}$, to jednak świadczyły o otwartości na dialog, niepoprzestajacy jedynie na neutralności i izolacji. Dlatego będąc skazanym na metafizykę i wiarę, warto otworzyć się na teologię, która jako wewnętrznie usystematyzowana, samokrytyczna refleksja oferuje jej wersję najbardziej racjonalna.

O możliwości twórczego dialogu nauk empirycznych i teologii byli w pełni przekonani Arthur Peacocke ${ }^{46}$ i John Polkinghorne ${ }^{47}$. W polskim środowisku naukowym taki pogląd reprezentują badacze związani z Centrum Kopernika Badań Interdyscyplinarnych. Dużo pisze się o warunkach wstępnych owocnego dialogu. Pabjan zaznacza, iż należą do nich respektowanie odmienności metodologicznej oraz rezygnacja z postaw fundamentalistycznych ${ }^{48}$. Warto zauważyć, iż Andrzej Anderwald wyróżnił aż sześć kryteriów dialogu: autonomia, integralność, językowa otwartość, poznawczo-interpretacyjna otwartość, ostrożność znaczeniowa wyrażeń oraz wychodząc z założenia, iż „postulat niewychodzenia poza rygorystycznie rozumiana naukową metodę jest nierealistyczny” ${ }^{49}$, proponuje „podjęcie teologicznej refleksji nad istnieniem, podstawami, metodami i wynikami

43 Por. M. Heller, J. Życiński, Pasja wiedzy..., dz. cyt., s. 222.

${ }_{44}$ Por. M. Heller, J. Życiński, Pasja wiedzy..., dz. cyt., s. 234; A. Anderwald, Teologia a nauki..., dz. cyt., s. 215.

45 Por. M. Heller, Nowa fizyka..., dz. cyt., s. 82.

46 Zob. A. Peacocke, Teologia i nauki przyrodnicze, tłum. L. M. Sokołowski, Kraków 1991; A. Peacocke, Drogi od nauki do Boga. Kres naszych wszelkich poszukiwań, tłum. J. Gilewicz, Poznań 2004.

47 Zob. zwłaszcza J. Polkinghorne, Rozum i rzeczywistość. Zwiazki między nauka i teologia, tłum. P. Tomaszek, Kraków 1995; J. Polkinghorne, Jeden świat. Wzajemne relacje nauki i teologii, tłum. M. Chojnacki, Kraków 2008; a także T. Pabjan, Anatomia konfliktu..., dz. cyt., s. 43, 130.

48 Por. T. Pabjan, Anatomia konfliktu..., dz. cyt., s. 9.

49 M. Heller, J. Życiński, Pasja wiedzy..., dz. cyt., s. 259; por. M. Heller, Nowa fizyka..., dz. cyt., s. 110: „Kurczowe trzymanie się ideologii metodologicznego roz- 
nauk" ${ }^{50}$, zwłaszcza w odniesieniu do nauk empirycznych. Teologia nauki tym różniłaby się od filozofii nauki, że spoglądałaby na metodologiczna granicę nauk i teologii nie od strony tych pierwszych, ale w perspektywie prawdy o stworzeniu świata przez Boga. Ponadto miałaby także ubogacić refleksję nauk przyrodniczych o wymiar aksjologiczny ${ }^{51}$. Od momentu zaprezentowania pierwszych deklaracji programowych teologii nauki w latach osiemdziesiątych dziedzina ta doczekała się kolejnych opracowań ${ }^{52}$. Warto zaznaczyć, iż teologia nauki przez lata rozwijała się w nurcie separacjonizmu metodologicznego, reprezentowanym przez ks. Józefa Turka ${ }^{53}$.

Nie zagłębiając się w dyskusję na temat zasadności obydwu podejść, chciałbym przedstawić przykład teologicznej refleksji nad problemem metodologicznych granic pomiędzy poznaniem wiary i poznaniem rozumu w myśli Wojciecha Giertycha.

\section{Od ontologii do metodologii - w kierunku integracji}

Ojciec Wojciech Giertych jest dominikańskim moralista, pełniącym urząd teologa Domu Papieskiego. W swej twórczości porusza szeroko rozumiane problemy teologii moralnej, za każdym razem

działu jest dziś anachronizmem. (...) Metodologia jest tylko narzędziem, a jeżeli ma istnieć postęp, to narzędzia muszą się doskonalić”.

50 M. Heller, Nowa fizyka..., dz. cyt., s. 150.

51 Por. M. Heller, Nowa fizyka..., dz. cyt., s. 152-154.

${ }^{52}$ Zob. J. Życiński, W poszukiwaniu teologii nauki, w: Nauka-religia-dzieje. II Seminarium Interdyscyplinarne w Castel Gandolfo, 6-9 września 1982 roku, red. J. A. Janik, P. Lenartowicz, Kraków 1984; M. Heller, Wstęp do teologii nauki, w: Teologia nauki, red. J. Mączka, P. Urbańczyk, Kraków 2015; W. M. Macek, Teologia nauki wedtug ks. Michała Hellera, Warszawa 2010; W. M. Macek, Teologia nauki, w: Oblicza racjonalności: wokót myśli Michała Hellera, red. B. Brożek, J. Mączka, W. P. Grygiel, M. L. Hohol, Kraków 2011, s. 203-238; P. Polak, Teologia nauki w perspektywie metodologicznej, w: Teologia nauki, red. J. Mączka, P. Urbańczyk, Kraków 2015; T. Maziarka, W stronę teologii nauki - na kanwie myśli ks. prof. Michała Hellera, „Tarnowskie Studia Teologiczne” 35 (2016) nr 1, s. 7-18.

${ }_{53}$ Por. J. Turek, Metodologiczne ograniczenia procedur unaukowienia teologii, „Roczniki Filozoficzne” 59 (2011) nr 2, s. 53-69; P. Polak, Teologia nauki..., dz. cyt., s. $40-51$. 
podkreślając rolę łaski i wiary nie tylko w życiu duchowym człowieka, ale także w uprawianiu teologii. Do często podejmowanych przez niego zagadnień należy również kwestia relacji pomiędzy wiarą i rozumem, którą naświetla od strony danych par excellence teologicznych. Relacja ta bezpośrednio przekłada się na rozumienie wzajemnego stosunku teologii i nauk, dlatego w mojej ocenie prezentowane przez Giertycha stanowisko można uznać za wkład w dziedzinę teologii nauki.

Punktem wyjścia w pojmowaniu relacji wiary i rozumu jest dla dominikańskiego teologa chalcedońska teologia. Sobór chalcedoński miał miejsce w 451 roku, a jednym z jego celów było doprecyzowanie doktryny papieża Leona Wielkiego o dwóch naturach Jezusa Chrystusa i ostateczne rozprawienie się z monofizycką herezja Eutychesa ${ }^{54}$. Ojcowie soborowi, rozważając tę kwestię, przyjęli w „Definicji wiary" następujace sformułowanie:

Jednego i tego samego Chrystusa Pana, Syna Jednorodzonego, należy wyznawać w dwóch naturach: bez zmieszania, bez zmiany, bez podzielenia i bez rozłączania. Nigdy nie zanikła różnica natur przez ich zjednoczenie, ale zostały zachowane cechy właściwe obu natur, które się spotkały, aby utworzyć jedną osobę ${ }^{55}$.

Giertych twierdzi, iż

(...) soborowe podkreślenie dwóch niezmieszanych (...) i nierozdzielonych natur w Jezusie można także odnieść do umysłu wierzącego człowieka. U wierzaccego musi być miejsce i dla rozumu, i dla wiary, które nie mają być wymieszane; nie bardzo byłoby wtedy wiadomo, czy w umyśle gości wiara, czy też wiedza. Rozum i wiara nie mają również być rozdzielone. To oznaczałoby, że te dwa porządki poznania funkcjonuja jako całkowicie skłócone wobec siebie lub też jako absolutnie paralelne i wobec siebie obojętne, co wskazywałoby na jakąś schizofrenię.

54 Por. Dokumenty Soborów Powszechnych. Tekst grecki, taciński, polski, t. I (325787), red. A. Baron, H. Pietras, Kraków 2005, s. 193.

55 Dokumenty Soborów..., red. A. Baron, H. Pietras, dz. cyt., s. 223. 
Rozum i wiara mają swoja godność, każde w swoim porządku, i muszą się wzajemnie szanować ${ }^{56}$.

Dominikański teolog reprezentuje zatem antyseparacjonistyczne stanowisko w teologii nauki. Kładzie akcent na integrację i zjednoczenie poznania teologicznego i poznania rozumowego, które - tak jak dwie natury Jezusa - połączone są w jednej, niepodzielnej osobie. Chodzi jednak o połaczenie bez zmieszania, szanujace metodologiczną odrębność właściwą każdemu z tych dwóch porządków. Giertych zwraca uwagę na zagrożenia, które płyną z ich pomieszania. Ze strony rozumu zagraża wierze tendencja do „pysznej samowystarczalności”, która albo traktuje wiarę jako formę wiedzy podporządkowanej jej kryteriom, albo wyklucza możliwość myślenia wewnątrz wiary, co wiąże się z przyznaniem wartości poznawczej jedynie naukom i z pogardliwym odrzuceniem teologii, traktowanej jako refleksja niegodna rozumu ${ }^{57}$. Mowa tu zatem o wracającej mentalności pozytywistycznej w postaci racjonalizmu i ontologizmu, które zakładały, iż rozum sam z siebie może poznać to, co jest poznawalne tylko w świetle wia$\mathrm{ry}^{58}$. Racjonalizm udziela się niektórym teologom, którzy poddając się nurtowi deprecjacji poznania wiary i kompleksowi niższości, bezkrytycznie ulegają wpływowi twierdzeń uznanych za filozoficznie uzasadnione i na nich, a nie na depozycie wiary, buduja teologię $e^{59}$. Jest to znane od starożytności zjawisko gnostycyzmu, który przerabiając wiarę na wiedzę, próbuje uzasadnić prawdy wiary na bazie czysto ludzkich kryteriów i przyjmuje je tylko w przypadku, gdy pozostaja one zgodne z wynikami badań nauk nie tylko empirycznych, ale także społecznych czy politycznych ${ }^{60}$. Ponadto rozum może:

(...) zredukować wiarę jedynie do aktu intelektualnego posłuszeństwa, co oznaczałoby, że wiara przestałaby być wkroczeniem objawio-

56 W. Giertych, Rozruch wiary, Pelplin 2012, s. 95-96.

57 Por. W. Giertych, Rozruch wiary, dz. cyt., s. 97.

58 Por. FR 52.

59 Por. FR 55.

${ }^{60}$ Por. W. Giertych, Rozruch wiary, dz. cyt., s. 98. Zjawisko to nazywane jest konkordyzmem. 
nej prawdy Bożej w życiu ludzkiego intelektu, a stałaby się jedynie ślepym poddaniem umysłu władzy boskiej czy kościelnej ${ }^{61}$.

Tymczasem jak to zostało już wyżej wspomniane, o płodności rozumu inspirowanego wiara - także na polu nauk przyrodniczych - poucza historia.

Należy także wspomnieć, iż zagrożenia dla rozumu ze strony wiary i tym samym dla nauk ze strony teologii sa równie groźne. Jak zauważa Jan Paweł II, także współcześnie świat teologii dotyka problem fideizmu, który pozbawia refleksję filozoficzną charakteru istotnego warunku nie tylko rozumienia wiary, ale samej możliwości wiary w Boga ${ }^{62}$.

Niemniej przy należytym odróżnieniu metodologicznym porządków rozumu i wiary, które zgodnie z zasadą chalcedońskiego połączenia szanuje ich autonomię i jednocześnie zakłada, a nie dowodzi ich niesprzeczności ${ }^{63}$, zarówno teologia, jak i nauki szczegółowe mogą wiele zyskać na wzajemnym dialogu. Giertych zauważa, że:

(...) rozum może zajmować się każdą nauką. Ale gdy jest równocześnie otwarty przez wiarę na Bożą tajemnicę, wie, że w każdej badanej rzeczywistości zachodzi jeszcze dodatkowy wymiar (...). Wiara więc (...) dostarcza umysłowi dodatkową korygująca perspektywę, która wychyla poznanie poza przedmiot naukowego poznania ${ }^{64}$.

Integracja poznania rozumu i wiary jest jednak możliwa przy założeniu, iż w wierze występuje miejsce na „myślenie z przyzwoleniem”65 i że nie może zaistnieć rozbieżność pomiędzy dwoma porządkami poznania ${ }^{66}$. W tej perspektywie teologia, będąca $\mathrm{w}$ istocie

61 W. Giertych, Odtruwanie taski, Kraków 2011, s. 213.

62 Por. FR 55.

63 Por. T. Pabjan, Anatomia konfliktu..., dz. cyt., s. 40; Jan Paweł II, Posłanie Jego Światobliwości Ojca Świętego Jana Pawła II do Ojca George’a V. Coyne’a Dyrektora Obserwatorium Watykańskiego, „Zagadnienia Filozoficzne w Nauce” XII (1990), s. $2-12$.

${ }^{64}$ W. Giertych, Rozruch wiary, dz. cyt., s. 116.

65 W. Giertych, Rozruch wiary, dz. cyt., s. 109.

66 Por. FR 53. 
myśleniem wewnątrz wiary, staje się, zdaniem Giertycha, królową wszystkich nauk. Rozważając prawdy objawione, teologowie wyciągają bowiem wnioski rzutujące na poznanie jakiejkolwiek innej rzeczywistości ${ }^{67}$. Owocny dialog zakłada zatem prymat wiary nad rozumem. Dominikański teolog podkreśla, iż:

(...) recepcja prawd wiary (...) wymaga dyspozycyjności umysłu, gotowego na to, że będzie się on formował według tajemniczych prawd wiary. Postawa nieufności wobec nich, przyjęta jako podstawowe założenie metodologiczne, zgodnie zresztą z kanonem myślenia sugerowanym przez liczne nowożytne kierunki filozoficzne, jest dla wiary rujnująca ${ }^{68}$.

Co jednak istotne - przyjęcie takich założeń wcale nie upokarza rozumu, zmuszając go do przyjęcia nieoczywistych prawd wiary, a jedynie przystosowuje go tak, aby przekraczał swoje naturalne granice w stronę tajemniczej prawdy ${ }^{69}$. Święty Augustyn streścił tę ideę w zdaniu: „Nagrodą za wiarę jest pojmowanie. Zatem nie szukaj zrozumienia, abyś wierzył, ale wierz, żebyś zrozumiał”.

Na koniec trzeba podkreślić, iż tak ukształtowana relacja wiary i rozumu oraz teologii i nauk ma swoje uzasadnienie antropologiczne. Sprawy wiary nie można sprowadzać tylko do poziomu poznania. Wiara zawsze pozostanie wpierw zawierzeniem, które nie daje pewności empirycznej czy matematycznej, i właśnie jako taka stanowi głęboko zakorzenioną w człowieku potrzebę przemiany wpisanej $\mathrm{w}$ naturę religijności ${ }^{70}$. Z tego tylko powodu nie może być traktowana jako irracjonalna, realizujacca się jedynie na poziomie sentymentów i pozbawiona walorów poznawczych ${ }^{71}$. Te ostatnie opierają się jednak nie na wynikach badań naukowych, ale na autorytecie samego Boga. Z powyższych względów wiara staje się pomocna nie tylko dla rozumu, poszerzając perspektywę poznawcza, ale dla całego

${ }^{67}$ Por. W. Giertych, Rozruch wiary, dz. cyt., s. 116.

68 W. Giertych, Odtruwanie łaski, dz. cyt., s. 215.

69 Por. W. Giertych, Odtruwanie taski, dz. cyt., s. 19.

70 Na temat relacji wiary i religijności zob. W. Giertych, Fides et actio, Warszawa 2012 , s. $17-34$.

71 Por. W. Giertych, Rozruch wiary, dz. cyt., s. 119. 
człowieka, pozwalając mu uniknacc duchowej schizofrenii powodowanej przez epistemologiczny redukcjonizm i „fragmentaryzację sensu”, do której skłania pokusa sceptycyzmu, a więc nieufności w możliwość poznania prawdy przez ludzki rozum ${ }^{72}$.

\section{Wnioski}

Z przyjęcia zasady chalcedońskiego zjednoczenia porządku wiary i rozumu w naturze ludzkiej płynie kilka zasadniczych wniosków, które w znacznej mierze pokrywają się z tezami współczesnej filozofii nauki.

Po pierwsze trzeba zauważyć, iż teologia nauki zaproponowana przez Giertycha nie tylko potwierdza wypracowana przez filozofię nauki zasadę niemieszania dwóch porządków poznawczych ${ }^{73}$, ale otwierając perspektywę dla rozumu, wykracza poza jego granice ${ }^{74}$. Można powiedzieć, że początkowe założenia teologii nauki pokrywają się z końcowymi wnioskami filozofii nauki. Ta ostatnia dochodzi do przekonania o konieczności wiary i przyjęcia jakiejś metafizyki, a także o nieuchronności wychodzenia ludzkiej ciekawości „poza bezpiecznie kontrolowane metodą regiony", co jest w istocie tożsame z postulatem ubogacenia spojrzenia naukowego o perspektywę racjonalnie przemyślanej wiary. Warto podkreślić, iż o ile pozytywistyczne przejście od metodologii do ontologii było nieuprawnione i katastrofalne w skutkach, o tyle teologiczne uzasadnienie metodologicznego niemieszania porządków wiary i rozumu, ufundowane na ontologii bytu Jezusa Chrystusa, wydaje się niezwykle trafne.

Po drugie obydwa wspomniane porządki nie wyniszczają się jedynie wtedy, gdy precyzyjnie rozdziela się kompetencje dyskursów. Dla przykładu - przeciwstawianie teologii stworzenia teorii ewolucji wynika właśnie z pomieszania kompetencji. Giertych zaznacza, iż:

72 Por. W. Giertych, Rozruch wiary, dz. cyt., s. 114; FR 5.

73 Dla porządku wspomnę, iż próby teologicznego uzasadniania tej zasady były już podejmowane w przeszłości, np. przez Georgesa Lemaĭtre’a. Zob. M. Heller, J. Życiński, Pasja wiedzy..., dz. cyt., s. 244.

${ }_{74}$ Por. M. Heller, Nowa fizyka..., dz. cyt., s. 152. 
Objawienie zawiera przesłanie o stworzeniu świata z niczego i jego podtrzymywaniu w istnieniu przez Boga oraz o stworzeniu człowieka na obraz i podobieństwo Boże, ale cała ideologiczna wrzawa wokół zagadnienia styku tegoż przesłania z wynikami nauk empirycznych jest w gruncie rzeczy niepotrzebna ${ }^{75}$.

Nauki te próbują bowiem znaleźć odpowiedź na pytanie, jak powstał obecny świat pod względem „technicznym”. Nie oznacza to, że nie mają one nic wspólnego z teologią. Można postawić pytanie o to, jak Bóg stworzył świat. Co więcej, takie pytanie wydaje się w pełni zasadne, gdyż ewolucja nie sprzeciwia się teologii stworzenia, ale uzupełnia ja, dając tym samym syntetyczny i całościowy obraz, możliwy do uzyskania właśnie poprzez metodologiczną analizę nauki i teologii ${ }^{76}$.

Po trzecie wiara nie jest konieczna dla uprawiania nauki. Nauki empiryczne przez ostatnie kilka stuleci wypracowały własne metody, które gwarantują im wysoką skuteczność. Ich ekspansywność rodzi jednak pokusę przekroczenia kompetencji i orzekania o tym, co nie jest przedmiotem ich badań. Na straży zachowania odrębności porządków stoi teologia jako rozwinięta dyscyplina naukowa, podejmująca racjonalną refleksję nad wiara, z silną świadomością własnych celów, przedmiotu i metod, których przestrzega co najmniej od czasów potwierdzenia tez Galileusza przez Newtona ${ }^{77}$. Niemniej rola teologii w dialogu z naukami nie musi sprowadzać się jedynie do funkcji negatywnej. Teologia ubogaca poznanie naukowe o nowe wymiary $^{78}$, a dodatkowo motywuje rozum, aby przekraczał naturalną pokusę izolacji, ponosząc ryzyko otwarcia na wartości piękna, dobra i ostatecznej Prawdy. W tej perspektywie wiara staje się zatem zdecydowanym obrońcą i sprzymierzeńcem rozumu ${ }^{79}$. Zachęca

75 W. Giertych, Odtruwanie taski, dz. cyt., s. 130.

76 Por. M. Heller, Nowa fizyka..., dz. cyt., s. 156.

77 Por. W. Giertych, Odtruwanie łaski, dz. cyt., s. 225.

78 Zob. zwłaszcza refleksję Woźniaka na temat teologicznego otwarcia na przyszłość i niedostatków ludzkiego rozumu: R. J. Woźniak, Przyszłość, teologia..., dz. cyt., s. 53-55.

79 Por. FR 56. 
go do stawiania pytań o najgłębszy sens i fundament życia ludzkiego i otwiera na świat w całym jego egzystencjalnym bogactwie. Jak słusznie zauważył ks. Robert Woźniak: „tylko synteza wiary i rozumu jest zarzewiem nigdzie indziej nieosiaganego twórczego zapału i umiejętności przekształcania świata ku przyszłości" ${ }^{\circ 0}$. W tym kontekście teologia może przyczynić się także do powrotu filozofii nowożytnej ze stanowiska wątpienia i niepewności na pozycje „optymistyczno-realistycznej koncepcji ludzkiego bycia w świecie”81.

Wreszcie warto przytoczyć na zakończenie słowa Hellera:

Intelektualny klimat uległ drastycznej zmianie. Silnie pozytywistyczne i scjentystyczne tendencje (...), skazujące filozofię i teologię na banicję z obszaru racjonalności, ustapiły miejsca tolerancji dla wszelkiego rodzaju ekscentrycznych doktryn. (...) Coraz częściej dochodzi do tego, że przedstawiciele nauki, filozofii i teologii, zagrożeni falą panoszącego się irracjonalizmu, ze zdziwieniem stwierdzaja, iż znajdują się w tym samym obozie obrońców racjonalności ${ }^{82}$.

Choćby zatem z tego powodu warto spoglądać na teologię życzliwym okiem.

\section{Summary}

From conflict to integration. The history and the theological justification of methodological autonomy of reason and faith

The history of relationship between faith and reason is marked by four models of the interaction between science and theology proposed by Ian G. Barbour: conflict, independence, dialogue and integration. Even if nineteenth-century positivism is still present in many scientists' minds, philosophy of science eventually managed to overcome it in the 1960s. A mutual distrust between faith and reason started to disappear. In this context Fr. Michał Heller presented a project of a new discipline - the theology of science which would look at the boundaries of the natural sciences from the theological point of view. According

80 R. J. Woźniak, Przyszłość, teologia..., dz. cyt., s. 54.

81 R. J. Woźniak, Przyszłość, teologia..., dz. cyt., s. 69.

82 M. Heller, J. Życiński, Pasja wiedzy..., dz. cyt., s. 260. 
to Fr. Wojciech Giertych the adequate model of relationship between faith and reason can be based theologically on Chalcedonian Christology of Jesus' two natures. Since reason and faith come together unconfusedly and inseparably in a human being, a mutual dialogue and even integration between theology and science is by all means possible.

Keywords: Fr. Wojciech Giertych, theology of science, methodology of science, reason and faith

\section{Bibliografia}

Anderwald A., Teologia a nauki przyrodnicze. Rola wiedzy przyrodniczej $w$ dociekaniach teologicznych, Opole 2007.

Barbour I. G., Jak układaja się stosunki między nauka a teologia?, tłum. S. Cyran i in., „Zagadnienia Filozoficzne w Nauce” XV (1993), s. 3-22.

Barbour I. G., Jak uktadaja się stosunki między naukq a teologia? Cz. II, tłum. S. Cyran i in., „Zagadnienia Filozoficzne w Nauce” XVI (1994), s. 3-22.

Dokumenty Soborów Powszechnych. Tekst grecki, taciński, polski, t. I (325787), red. A. Baron, H. Pietras, Kraków 2005.

Giertych W., Fides et actio, Warszawa 2012.

Giertych W., Odtruwanie łaski, Kraków 2011.

Giertych W., Rozruch wiary, Pelplin 2012.

Heller M., Filozofia i wszechświat. Wybór pism, Kraków 2008.

Heller M., Nowa fizyka i nowa teologia, Kraków 2015.

Heller M., Wstep do teologii nauki, w: Teologia nauki, red. J. Mączka, P. Urbańczyk, Kraków 2015.

Heller M., Wszechświat i Stowo, Kraków 1994.

Heller M., Życiński J., Pasja wiedzy. Między nauka a filozofia, Kraków 2010.

Jammer M., The Concepts of Mass, Cambridge 1961.

Jan Paweł II, encyklika Fides et ratio, Wrocław 1998.

Jan Paweł II, Postanie Jego Światobliwości Ojca Świętego Jana Pawła II do Ojca George'a V. Coyne’a Dyrektora Obserwatorium Watykańskiego, „Zagadnienia Filozoficzne w Nauce” XII (1990), s. 2-12.

Jelonek T., Biblijna historia zbawienia, Kraków 2004. 
Jodkowski K., Spór ewolucjonizmu z kreacjonizmem. Podstawowe pojęcia i poglady, Warszawa 2007.

Macek W. M., Teologia nauki wedtug ks. Michała Hellera, Warszawa 2010.

Macek W. M., Teologia nauki, w: Oblicza racjonalności: wokót myśli Michała Hellera, red. B. Brożek, J. Mączka, W. P. Grygiel, M. L. Hohol, Kraków 2011.

Maziarka T., W stronę teologii nauki-na kanwie myśli ks. prof. Michała Hellera, „Tarnowskie Studia Teologiczne” 35 (2016) nr 1, s. 7-18.

Międzynarodowa Komisja Teologiczna, W poszukiwaniu etyki uniwersalnej: nowe spojrzenie na prawo naturalne, tłum. R. Kiełtyka, Kraków 2010.

Nauka - religia - dzieje. II Seminarium Interdyscyplinarne w Castel Gandolfo, 6-9 września 1982 roku, red. J. A. Janik, P. Lenartowicz, Kraków 1984.

Pabjan T., Anatomia konfliktu. Między nowym ateizmem a teologia nauki, Kraków 2016.

Peacocke A., Drogi od nauki do Boga. Kres naszych wszelkich poszukiwań, tłum. J. Gilewicz, Poznań 2004.

Peacocke A., Teologia i nauki przyrodnicze, tłum. L. M. Sokołowski, Kraków 1991.

Pedersen O., Konflikt czy symbioza? Z dziejów relacji pomiędzy nauka a teologia, tłum. W. Skoczny, Tarnów 1997.

Polak P., Teologia nauki w perspektywie metodologicznej, w: Teologia nauki, red. J. Maczka, P. Urbańczyk, Kraków 2015.

Polkinghorne J., Jeden świat. Wzajemne relacje nauki i teologii, tłum. M. Chojnacki, Kraków 2008.

Polkinghorne J., Rozum i rzeczywistość. Zwiazki między nauka i teologia, tłum. P. Tomaszek, Kraków 1995.

Szymik J., Teologia jako nauka wiary, czyli scientia sui generis, „Śląskie Studia Historyczno-Teologiczne" XXXII (1999), s. 95-104.

Torrance T. F., Space, Time and Incarnation, Oxford 1969.

Turek J., Metodologiczne ograniczenia procedur unaukowienia teologii, „Roczniki Filozoficzne" 59 (2011) nr 2, s. 53-69.

Woźniak R. J., Przyszłość, teologia, społeczeństwo, Kraków 2007. 